\title{
EFFECT OF GAMMA RADIATION ON THE INACTIVATION OF AFLATOXIN B1 IN FOOD AND FEED CROPS
}

\author{
I. Ghanem*; M. Orfi; M. Shamma \\ Atomic Energy Commission of Syria, Department of Molecular Biology and Biotechnology, Damascus \\ Submitted: September 23, 2007; Returned to authors for corrections: February 26, 2007; Approved: October 22, 2008.
}

\begin{abstract}
Samples of food crops (peanut, peeled pistachio, unpeeled pistachio, rice, and corn) and feed (barley, bran, corn) were autoclave-sterilized, and inoculated with $10^{6}$ of spore suspension of an isolate of Aspergillus flavus fungus known to produce aflatoxin B1 (AFB1). Following a 10-day period of incubation at $27 \mathrm{C}$ to allow for fungal growth, food and feed samples were irradiated with gamma radiation at the doses 4, 6, and $10 \mathrm{kGy}$. Results indicated that degradation of AFB1 was positively correlated with the increase in the applied dose of gamma ray for each tested sample. At a dose of $10 \mathrm{kGy}$ percentages of AFB1 degradation reached highest values at 58.6, 68.8, 84.6, 81.1 and $87.8 \%$ for peanuts, peeled pistachios, unpeeled pistachios, corn and rice samples, respectively. In feed samples percentages of AFB1 degradation were 45, 66, and $90 \%$ in barley, 47, 75, and $86 \%$ in bran, and 31,72 , and $84 \%$ in corn for the doses of 4,6 , and $10 \mathrm{kGy}$, respectively. AFB1 degradation in food samples correlated negatively with oil content in irradiated samples. Thus, in peanuts, which contained the highest oil content, percentage of AFB1 degradation at $10 \mathrm{kGy}$ was not more than $56.6 \%$, whereas, the corresponding value in corn, which contained the lowest oil content, reached as high as $80 \%$. The above results indicate the possibility of using gamma radiation as a means of degradation of AFB1 in food and feed crops to levels lower than the maximum allowed levels.
\end{abstract}

Key words: Aflatoxin B1, food feed, gamma radiation

\section{INTRODUCTION}

AFB1 is one of four toxic, secondary metabolites produced by the food spoilage fungi Aspergillus particularly A. flavus and $A$. paraciticus (4). The aflatoxins are highly carcinogenic agents, and AFB1 is listed as a carcinogen of group 1 by the International Agency for Research on Cancer $(4,8)$. Toxic and carcinogenic effects of AFB1 are thought to be related to its metabolism by cellular enzymes. Oxidative derivatives produced from the metabolism of AFB1 include hydroxylated species such as AFM1 as well as covalent macromolecular adducts with DNA and proteins. Biological consequences of oxidative metabolism of AFB1 range from cellular transformation to cell death $(8,13)$.

Food and Agricultural organization (FAO) estimated that as much as $25 \%$ of the world's agricultural commodities are contaminated with mycotoxins, leading to significant economic losses (10). The prevention of aflatoxin contamination prior to harvest or during post-harvest and storage is not always possible, necessitating decontamination before the use of such materials for food and feed use $(3,10,15)$. Various detoxification procedures play an important role in helping prevent exposure to the toxic and carcinogenic effect of aflatoxins. Detoxification of aflatoxins is achieved by removal or elimination of the contaminated commodities or by inactivation of the toxins present in these commodities by physical, chemical, or biological methods $(10,18)$. Blending of certain mycotoxin-contaminated raw materials to produce a final blended feed below the critical level of contamination is permitted, with some limitations, in several countries $(6,21)$. However, detoxification of products by chemical treatments is not allowed in the European Union, also, the mixing of contaminated products with good quality products is prohibited (10).

*Corresponding Author. Mailing address: Atomic Energy Commission of Syria, Department of Molecular Biology and Biotechnology, Damascus P.O. Box: 6091. Fax: +963-11-6112289. E-mail: eghanem@aec.org.sy 
Despite much public debate on the safety of irradiated foods ionizing radiation is becoming more frequently used in the sterilization of a wide variety of foods $(10,16)$. In 1980 the JECFI indicated that irradiation of any food commodity up to an average dose of $10 \mathrm{kGy}$ causes no toxicological hazards and no special microbiological or nutritional problems (10). As well as proving useful in the post harvest control of mycotoxins in storage through prevention of mould growth and subsequently prevention of mycotoxin formation, ionizing radiation has been investigated as a method for the degradation of mycotoxins, including aflatoxins, with conflicting results depending on the matrix and the experimental setup $(10,11,14)$.

The purpose of the present study was to assess the effect of gamma radiation on the breakdown of AFB1 in several food and feed products following inoculation, in the lab, of these products with a strain of $A$. flavus known to produce aflatoxin B1.

\section{MATERIALS AND METHODS}

\section{Inoculation with the fungus}

A strain of $A$. flavus known to produce aflatoxin $\mathrm{B} 1$ was grown on PDA for 10 days at $27^{\circ} \mathrm{C}$. Samples $(100 \mathrm{~g})$ of food (rice, pistachios, peanuts and corn), and feed (wheat, corn and bran) were Placed in $1 \mathrm{~L}$ flasks and wetted with $15 \mathrm{ml}$ of water. The samples were sterilized in an autoclave $\left(\right.$ at $100^{\circ} \mathrm{C}$ and under 15 bar pressure) and inoculated with $10^{6}$ spore suspension $(2 \mathrm{ml})$ of the fungus A. flavus. Inoculated samples were left for 10 days at $27^{\circ} \mathrm{C}$ to allow for fungus growth. Following inoculation with the fungus each food and feed sample was mixed thoroughly in order to obtain homogeneity.

\section{Irradiation with gamma ray}

Following thorough mixing, each sample was divided into $25 \mathrm{~g}$ sub-samples, each of which was placed in transparent plastic bags. Samples were irradiated in a gamma chamber which has ${ }^{60} \mathrm{Co}$ as the radiation source (Issledo-vatel UNIT MAX-1; Atomic Energy Commission of Syria). The radioactivity of the source was $2.51 \mathrm{KCi}$, and the dose rate at irradiation was 1.449 $\mathrm{kGy} \mathrm{hr}{ }^{-1}$ and irradiation was performed at $28^{\circ} \mathrm{C} \pm 2^{\circ} \mathrm{C}$. Doses of radiation applied were 4,6 , and $10 \mathrm{kGy}$. The experiments were done on three replicates for each radiation dose and for each food and feed sample. Three control replicates were assigned for each irradiation dose.

\section{Aflatoxin extraction and clean up}

AFB1 was extracted from food and feed samples using the method described in by De Gastro and Vorgas (7) with some modifications. Samples were ground to 20 mesh. Three hundred $\mathrm{ml}$ of chloroform and $10 \mathrm{ml}$ of distilled water were added to twenty five grams of ground sample. The mixture was homogenized in an Omni Mixer (IKA, Germany), and filtered through a No. 4 filter (Whatman). Anhydrous sodium sulphate
(20 g) were added to the filtrate which was passed once more through a filter paper (no. 4). A hundred $\mathrm{ml}$ of the filtrate was partially evaporated using a rotary evaporator (BUCHI, Switzerland). The evaporate was transferred into a $5 \mathrm{ml}$ bottle evaporation flask was rinsed with chloroform which was added to the evaporate. The sample was evaporated to complete dryness using a stream of nitrogen. The sample was reconstituted in $5 \mathrm{ml}$ of chloroform.

Clean-up of samples from oil-crops (i.e. corn peanuts and pistachios) was performed according to CAMAG method using a silica gel cartridge (5). The silica cartridge was conditioned by passing $6 \mathrm{ml}$ of toluene : acetonitrile $(98: 2, \mathrm{v}: \mathrm{v})$. The extract was applied to the surface of the silica cartridge and was washed with $20 \mathrm{ml}$ of toluene: acetic acid $(9: 1, \mathrm{v}: \mathrm{v})$, followed by $20 \mathrm{ml}$ of hexane : diethylether : acetonitrile $(6: 3: 1, \mathrm{v}: \mathrm{v})$. Aflatoxin B1 was eluted from the cartridge using 6 and $8 \mathrm{ml}$ of dichloromethane : acetone $(3: 1, \mathrm{v}: \mathrm{v})$. The sample $(15 \mathrm{ml})$ was concentrated using a stream of nitrogen and the final volume was adjusted to $2 \mathrm{ml}$.

Aflatoxin recovery using the above method on corn sample (3 replicates) spiked with 20 ppm of aflatoxin B1 was $80 \%$.

\section{Aflatoxin quantification}

AFB1 was quantified using TLC according to CAMAG method (5). Samples were applied on an F254 ${ }_{\text {nm }}$ TLC plate (CAMAG, Switzerland) together with known concentrations of standard solution of Aflatoxin B1. TLC plates were developed using a mixture of chloroform : acetone: water $(88: 12: 1.5, \mathrm{v}: \mathrm{v})$. The presence of aflatoxin B1 in the samples was detected using a TLC scanner (CAMAG, Switzerland) at a UV wave length of 254 nanometer. Concentration of aflatoxin was estimated from a calibration curve created by measuring the absorbance at 254 nanometer of known concentrations of aflatoxin standards.

\section{Statistical analysis}

StatView statistical Program (1) was used to analyze the statistical significance of experimental data. Results of aflatoxin concentrations in analyzed samples were subjected to ANOVA using Fisher's LSD.

\section{RESULTS AND DISCUSSION}

The effect of gamma radiation on the breakdown of AFB1 in food products inoculated with a strain of A. flavus known to produce aflatoxin B1 was studied. Concentrations of AFB1 produced two weeks following inoculation with $A$. flavus differed significantly $(\mathrm{p} \leq 0.01)$ between inoculated food products. The highest concentration of AFB1 was found in peanuts at $16 \mathrm{mg} \mathrm{kg}^{-1}$ which was significantly different $(\mathrm{p} \leq 0.01)$ than AFB1 concentrations found in other tested crops whereas, the lowest concentration of aflatoxin $\mathrm{B} 1$ was produced in corn at $6.6 \mathrm{mg} \mathrm{kg}^{-1}$. NO significant difference in AFB1 concentrations between peeled and unpeeled pistachios was found, nor was 
there any significant difference in AFB1 concentrations found in corn and rice crops. The rate of growth of toxin-producing fungi and aflatoxin production depends generally on the prevailing physical, biological biochemical and environmental conditions (12). However, in the present work all physical and environmental conditions were fixed for all inoculated food products since inoculation was conducted in the laboratory on sterilized samples and under temperature controlled environment. Hence, the difference in aflatoxin production between various commodities may be related to biochemical conditions within each commodity. It was found that the source of carbohydrates available to A. flavus greatly influences aflatoxin production (22).

In all tested commodities a positive correlation was found between the increase in doses of gamma radiation applied to the commodity and the level of breakdown of AFB1 present in this commodity, however, the maximum achievable level of aflatoxin breakdown varied between tested food products. In peanuts and at $10 \mathrm{kGy}$ of gamma radiation the highest achievable level of aflatoxin breakdown was only $58 \%$ of the total amount initially present. It was significantly $(\mathrm{p} \leq 0.01)$ higher than the levels of breakdown achieved by the doses of 6 and $4 \mathrm{kGy}$ which were $28.5 \%$ and $8 \%$, respectively. In peeled pistachios there was no significant difference in aflatoxin degradation between the dose $4 \mathrm{kGy}$ and that of the control treatment (dose $0 \mathrm{kGy}$ ), however, percentages of aflatoxin B1 degradation at the doses 4,6 , and $10 \mathrm{kGy}$ were significantly different averaging at $9.3,32$ and $69 \%$, respectively. The highest level of aflatoxin degradation in unpeeled pistachios $(85 \%)$ was significantly higher $(p \leq 0.01)$ than that in peeled pistachio $(69 \%)$. This may be explained by the fact that in unpeeled pistachios most of fungal growth was limited to the surface of the peel and limited amount of $A$ flavus growth managed to enter into the kernel itself. This meant that most of produced aflatoxin was not embedded in the kernel which made the breakdown of aflatoxin by gamma radiation easier.

In corn samples, significant degradation of aflatoxin $(p \leq 0.01)$ was observed between samples irradiated with 6 and $10 \mathrm{kGy}$ compared to non-irradiated samples however, no significant difference was observed when samples were irradiated with $4 \mathrm{kGy}$. Irradiation of rice samples resulted in most pronounced effect of radiation on AFB1 degradation. At 4,6 , and $10 \mathrm{kGy}$, levels of AFB1 were significantly ( $\mathrm{p} \leq 0.01$ ) reduced to $4.8,3$, and $1 \mathrm{mg} \mathrm{Kg}^{-1}$, compared to $8.6 \mathrm{mg} \mathrm{Kg}^{-1}$ in non-irradiated samples, with maximum percent degradation of $88 \%$ at $10 \mathrm{kGy}$ dose.

Several studies on the effect of gamma rays on aflatoxin degradation have been conducted with conflicting results. Hooshmand and Klopfedtein (11) reported that a dose of 20 kGy did not significantly affect AFB1 in any of the wheat, corn and soybean samples tested. Similarly doses of 15, 20, and 30 $\mathrm{kGy}$ of gamma radiation resulted in the destruction of $55-64 \%$ only of AFB1 in peanut samples (14). In a study on the effect of gamma radiation on the breakdown of AFB1, it was found that $10 \mathrm{kGy}$ of gamma radiation was sufficient to breakdown AFB1 completely in contaminated corn samples (2), whereas, results reported in the present study showed that at $10 \mathrm{kGy}$ the maximum achievable percentage of AFB1 breakdown in corn samples was $80 \%$ (Table 1). This difference between the above two studies in aflatoxin degradation at $10 \mathrm{kGy}$ may be related to the amount of AFB1 present in the sample before irradiation. Aquino et al. (2) used in their study naturally contaminated corn samples which contained on average $2.2 \mathrm{mg} \mathrm{Kg}^{-1}$ of AFB1, whereas, in the present study corn samples were artificially inoculated and the concentration of AFB1 in the samples before irradiation averaged at $6.6 \mathrm{mg} \mathrm{Kg}^{-1}$. Both studies used TLC to separate AFB1 from the rest of the sample and, in the case of Aquino et al. study (2) AFB1 was quantified using UV spectrophotometer, whereas, in the present study, a TLC scanner was used for the same purpose. It is possible that in the above mentioned study (2) the amount of AFB1 left in the sample following irradiation with $10 \mathrm{kGy}$ of gamma rays dropped below the detection limit of the UV spectrophotometer considering the initial amount of AFB1 present in the sample prior to irradiation (the highest amount reported of AFB1 was $2.59 \mathrm{mg}$ $\left.\mathrm{Kg}^{-1}\right)$. The detection limit reported in Aquino et al. study (2) was $2 \mu \mathrm{g} \mathrm{Kg}^{-1}$. AFB1 extraction procedures used by Aquino et al. (2) was according to the method reported by Soare and Rodrigues-Amaya.(19) and Sekiyama et al. (17) with one major modification, i.e. the reduction of sample size from $50 \mathrm{~g}$ to $25 \mathrm{~g}$ (2). Using only half the recommended sample size (2), and baring in mind that the extraction procedures end up using only a quarter of the original sample $(17,19)$, it is, therefore, conceivable that in Aquino et al. study (2) exposing samples to $10 \mathrm{kGy}$ of gamma radiation has resulted in the amount of AFB1 dropping to levels below the $2 \mu \mathrm{g} \mathrm{Kg}^{-1}$-detection limit reported by the above study (2) leading to the stated conclusion that AFB1 was completely destroyed by the application of $10 \mathrm{kGy}$ of gamma radiation (2).

Table 1 shows the effect of gamma radiation on AFB1 degradation in feed samples. The concentration of AFB1 in feed samples two weeks following inoculation with A. flavus was $6.3,6.7$, and 9.6 for barley, bran, and corn respectively. Similar to food samples, degradation of AFB1 in feed samples increased proportionally with the increase in the dose of gamma radiation. At $10 \mathrm{kGy}$ the highest percentage of AFB1 degradation was achieved reaching 90,86 , and $84 \%$ for barley, bran, and corn, respectively (Table 1 ).

In oil-crop food samples (i.e. corn, pistachios, and peanuts), a negative correlation was observed between percentage of oil content of these crops and percentage of AFB1 degradation. Percentage of oil content in those crops was estimated based on the weight of the solvent extractable oil during aflatoxin extraction related to the weight of the sample before extraction. 
Table 1. Effect of gamma radiation on aflatoxin degradation in feed products.

\begin{tabular}{cccc}
\hline \multirow{2}{*}{ Radiation Dose (kGy) } & \multicolumn{3}{c}{ Aflatoxin concentration $\left(\mathrm{mg} \mathrm{kg}^{-1}\right) \pm$ S. D. (\% degradation) } \\
\cline { 2 - 4 } & Barley & Bran & Corn \\
\hline 0 & A6.41 $\pm 0.61 \mathrm{~d}$ & $\mathrm{~B} 6.67 \pm 0.7 \mathrm{c}$ & $\mathrm{B} 9.62 \pm 0.56 \mathrm{c}$ \\
4 & $\mathrm{~A} 3.52 \pm 0.29 \mathrm{c}(45.04 \%)$ & $\mathrm{A} 3.53 \pm 1.05 \mathrm{~b}(52.94 \%)$ & $\mathrm{B} 6.63 \pm 1.24 \mathrm{~b}(31.21 \%)$ \\
6 & $\mathrm{~A} 2.15 \pm 0.14 \mathrm{~b}(66.19 \%)$ & $\mathrm{A} 1.63 \pm 0.68 \mathrm{ab}(75.54 \%)$ & $\mathrm{A} 2.68 \pm 1.00 \mathrm{a}(72.11 \%)$ \\
10 & $\mathrm{~A} 6.65 \pm 0.10 \mathrm{a}(89.86 \%)$ & $\mathrm{A} 0.9 \pm 0.1 \mathrm{a}(86 \%)$ & $\mathrm{B} 1.52 \pm 0.2 \mathrm{a}(84.23)$ \\
\hline
\end{tabular}

*Numbers within each column followed by different small letters are significantly different $(\mathrm{p}<0.01)$;

${ }^{\$}$ Numbers within each row followed by different capital leteers are significantly different $(\mathrm{p}<0.01)$.

Thus, percentages of AFB1 degradation at $10 \mathrm{kGy}$ was $80 \%$, $69 \%$, and $58 \%$, corresponding to percentages of oil content of $16 \%, 32 \%$, and $38 \%$ for corn, pistachios, and peanuts, respectively (Fig. 1).

In the present study we were unable to identify the breakdown products of AFB1 as a result of gamma irradiation, nor was it possible to study the toxicity of these products. However, a study on the effect of gamma radiation on the breakdown of AFB1 in water solution using Ames microsome mutagenicity test as an indicator of AFB1 breakdown to a nongenotoxic product showed that a dose of $10 \mathrm{kGy}$ of gamma radiation resulted in a total destruction and loss of toxicity breakdown product of AFB1 (20). Moreover, a study on chemical degradation of AFB1 produced by a culture of $A$. parasiticus using hydrogen peroxide showed that the main degradation product of AFB1 was non-fluorescent on TLC plate when exposed to UV light, and was not toxic for ducklings at an oral dose as high as 400 micrograms per $50 \mathrm{~g}$ body weight, nor did it have any mutagenic effect on Salmonella typhimurium using the Ames microsome mutagenicity test (9).

From the results presented in the present study, it can be concluded that it is possible to use gamma radiation, within the

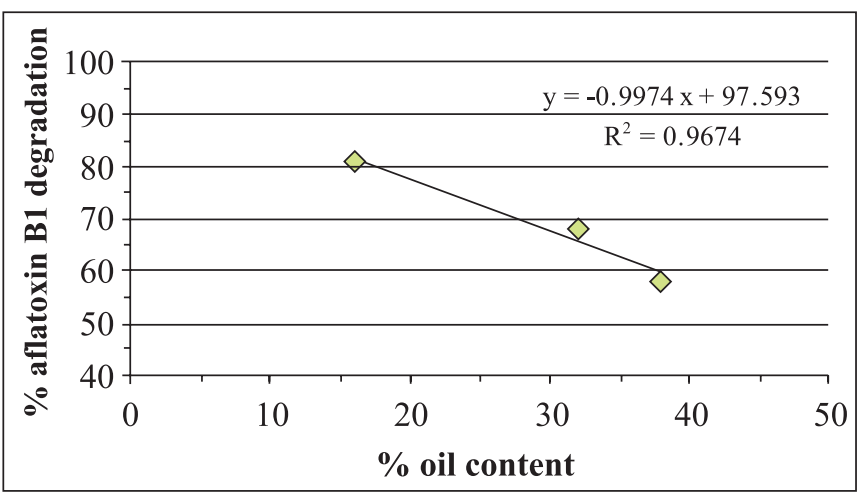

Figure 1. Correlation between oil content in food oil- crops and aflatoxin B1 degradation. maximum permitted dose, as a means for breakdown of AFB1 in contaminated food and feed stuff to below the maximum permitted levels. The degree of breakdown of AFB1 in food and feed varies according to the commodity and it may be related to oil content in oil crops.

\section{RESUMO}

\section{Efeito da radiação gama na inativação de aflatoxina B1 em alimentos e ração}

Amostras de alimentos (amendoim, pistache descascada, pistache com casca, arroz e milho) e de ração (cevada, farelo de trigo e milho) foram esterilizadas por autoclavação e inoculadas com uma suspensão de esporos $\left(10^{6}\right)$ de um isolado de Aspergillus flavus produtor de aflatoxina B1 (AFB1). Após incubação por 10 dias a $27^{\circ} \mathrm{C}$ para multiplicação do fungo, as amostras foram irradiadas com radiação gama nas doses de 4, 6 e 10 kGy. Os resultados indicaram que a degradação da AFB1 correlacionou-se positivamente com o aumento da dose de radiação gama. As porcentagens de degradação da AFB1 foram mais altas na dose de $10 \mathrm{kGy}$, obtendo-se valores de 58,6, 68,8, $84,6,81,1$ e 87,8\% para amendoim, pistache descascada, pistache com casca, milho e arroz, respectivamente. Nas rações, as porcentagens de degradação de AFB1 foram 45, 66 e 90\% para cevada, 47,75 e $86 \%$ para farelo de trigo e 31,72 e $84 \%$ para milho, nas doses de 4, 6 e 10 kGy, respectivamente. A degradação de AFB1 correlacionou-se negativamente com o teor de gordura nas amostras irradiadas. Assim, em amendoim, que apresentou o teor de gordura mais alto, a porcentagem de degradação com $10 \mathrm{kGy}$ foi inferior a $56,6 \%$, enquanto o valor correspondente em milho, que apresentou o teor de gordura mais baixo, foi de $80 \%$. Os resultados indicam a possibilidade de uso da radiação gama como meio de degradação de AFB1 em alimentos e ração a níveis inferiores ao máximo permitido.

Palavras-chave: aflatoxina $\mathrm{B} 1$, alimentos, ração, radiação gama 


\section{REFERENCES}

1. Abacus Concepts. (1996). Statview 4.5 statistical program. Abacus Concepts Corporation Berkeley, CA, USA.

2. Aquino, S.; Ferreira, F.; Rhbeiro, D.H.B.; Correa, B.; Greiner, R.; Villavicencio, A.L.C.H. (2005). Evaluation of viability of Aspergillus flavus and aflatoxins degradation_in irradiated samples of maize. Braz. J. Microbiol., 36: 352-356

3. Bata, A.; Lasztity, R. (1999). Detoxification of mycotoxincontaminated food and feed by microorganisms. Trends Food Sci. Technol., 10, 223-228.

4. Blesa, J.; Soriano, J.M.; Molto, J.C.; Marin, R.; Manes, J. (2003). Determination of aflatoxins in peanuts by matrix solid-phase dispersion and liquid chromatography. J. Chromatogr. A, 1011, 94-95.

5. CAMAG (1997). Determination of aflatoxins B1, B2, G1, G2 in foodstuffs, Application Notes, Instrumental Thin-Layer Chromatography.

6. Carlson, M.P. (2003). Use of feed contaminated with fungal (mold) toxins (mycotoxins). NebGuide Nebraska Cooperative Extension G03-1514-A (http://ianrpubs.unl.edu/plantdisease/g1514.htm)

7. De Castro, L.; Vargas, E.A. (2001). Determining aflatoxins B1, B2, G1, G2 in maize using florisil clean up with thin layer chromatography and visual and densitometric quantification, Cienc. Tecnol. Aliment., Campinas, 21(1): 115-122,

8. Groopman, J.D; Donahue, P.R.; Zhu, J.; Wogan, G.N. (1985). Aflatoxin metabolism in humans: Detection of metabolites and nucleic acid adducts in urine by affinity chromatography. Proc. Natl. Acad. Sci., USA, 82, 6492-6496.

9. Huynh, V.L.; Geredes, R.G.; Lloyd, A.B (1984). Synthesis and degradation of aflatoxins by Aspergillus parasiticus. II. Comparative toxicity and mutagenicity of aflatoxin B1 and its autolytic breakdown products. Aust. J. Biol. Sci., 37(3), 123-129.

10. Kabak, B.; Dobson, A.D.W.; Var, I. (2006). Strategies to prevent mycotoxin contamination of food and animal feed: A review. Crit. Rev. Food Sci. Nutr., 46, 593-619.

11. Hooshmand, H.; Klopfenstein, C.F (1995). Effects of gamma irradiation on mycotoxin disappearance and amino acid contents of corn, wheat, and soybeans with different moisture contents. J. Plants Foods Hum. Nutr.

12. Otta, K.H.; Papp, E.; Bagoesi, B. (2000). Determination of aflatoxins in food by overpressured-layer chromatography. J. Chromatogr. A, 882, 11-16.

13. Peraica, M.; Radic, B.; Lusic, A.; Pavlovic, M. (1999). Toxic effects of mycotoxins in humans. Bull. World Health Organ., 77(9), 754-766.

14. Prado, G.; De Carvalho, E.P.; Oliveira, M.S.; Madeira, J.G.C.; Morais, V.D.; Correa, R.F.; Cardoso, V.N.; Soares, T.V.; da Silva, J.F.M.; Goncalves, R.C.P. (2003). Effect of gamma irradiation on the inactivation of aflatoxin B1 and fungal flora in peanut. Braz. $J$. Microbiol., 34 (Suppl.1): 138-140.

15. Riley, R.T.; Norred, W.P. (1999). Mycotoxin prevention and decontamination- a case study on maize. Food, Nutr. Agric., 23, $25-$ 30, FAO publication.

16. Rosa, J.; Barbosa-Canovas, G.V. (2003). Nonthermal preservation of foods using combined processing techniques. Crit. Rev. Food Sci. Nutr., 43, 265-285.

17. Sekiyama, B.L.; Ribeiro, A.B.; Machinski, P.A.; Machinski Jr., M.M (2005). Aflatoxins, ochratoxin and zearalenone in maize-based food products. Braz. J. Microbiol., 36, 289-294.

18. Sinha, K.K. (1998). Detoxification of mycotoxins and food safety. In: Sinha, K.K.; Bhatnagar, D., Eds., Mycotoxins Agric. Food Saf. Marcel Dekker, INC., New York, 381-405.

19. Soares, L.M.V.; Rodrigues-Amaya, D.B (1989). Survey of aflatoxins, Ochratoxin A, zearalenone and stregmatocystin in some Brazilian foods by using multitoxin thin-layer chromatogy. J. Assoc. Off. Anal. Chem., 72, 22-26, 1989.

20. Van Dyck, P.J.; Tobback, P.; Feys, M.; Van De Voorde, H. (1982) Sensitivity of Aflatoxin B1 to Ionizing Radiation. Appl. Environ. Microbiol., Vol 43(6), P. 1317-1319.

21. Varga, J.; Toth, B. (2005). Novel strategies to control mycotoxins in feeds: A review. Acta Vet. Hung., 53(2), 189-203.

22. Woloshuk, C.B.; Cavaletto, J.R.; Cleveland, T.E. (1997). Inducers of aflatoxin biosynthesis from colonized maize kernels are generated by an amylase activity from Aspergillus flavus. Phytopathology, $87(2), 164-169$ 